Article

\title{
Sustainable Management Options for Healthy Rivers in South Asia: The Case of Brahmaputra
}

\author{
Neera Shrestha Pradhan ${ }^{1, *}$, Partha Jyoti Das ${ }^{2}$, Nishikant Gupta ${ }^{1}$ and Arun Bhakta Shrestha ${ }^{1}$ \\ 1 International Centre for Integrated Mountain Development (ICIMOD), Lalitpur 44700, Nepal; \\ nishikant.gupta@icimod.org (N.G.); arun.shrestha@icimod.org (A.B.S.) \\ 2 Water, Climate and Hazard Division, Aaranyak, Guwahati 781028, India; parthajdas@gmail.com \\ * Correspondence: neera.pradhan@icimod.org
}

Citation: Pradhan, N.S.; Das, P.J.; Gupta, N.; Shrestha, A.B. Sustainable Management Options for Healthy Rivers in South Asia: The Case of Brahmaputra. Sustainability 2021, 13, 1087. https://doi.org/10.3390/ su13031087

Received: 30 October 2020 Accepted: 17 December 2020 Published: 21 January 2021

Publisher's Note: MDPI stays neutral with regard to jurisdictional clai$\mathrm{ms}$ in published maps and institutional affiliations.

Copyright: (C) 2021 by the authors. Licensee MDPI, Basel, Switzerland. This article is an open access article distributed under the terms and conditions of the Creative Commons Attribution (CC BY) license (https:// creativecommons.org/licenses/by/ $4.0 /)$.
Abstract: The Brahmaputra is one of the largest river systems of South Asia, providing life-supporting services to about 70 million people. Massive flooding, land erosion, over-exploitation of water, excessive fishing, habitat degradation and fragmentation, exploitation of flood plains, climate change impacts, absence of integrated basin wide management, and transboundary cooperation are major challenges for the present and future sustainability and development in the basin. Although hydrological connectivity is intact in most of the main course of the river, the infrastructure development plans may convert the Brahmaputra to a predominantly managed river system. In this regard, this paper examines the physiographic, ecological, hydrological, and socioeconomic status of the Brahmaputra river, its transnational basin in South Asia, and the basin population in the cross-cutting context to explore its sustainable management options. For a durable future of the river and its communities, an integrated management mechanism among the basin countries with the objective of equitable benefit sharing, disaster risk management, and resilience building is needed. The suggested strategies will help in maintaining the ecohydrological health and utilitarian services of the river for the socioeconomic development of millions of poor and marginalized people living in the basin.

Keywords: river connectivity; freshwater ecosystem; multi-hazard scenario; transboundary cooperation; river basin management

\section{Introduction}

The Hindu Kush Himalayan (HKH) region is home to 10 major river basins of Asia and covers a territory that is over 4.2 million $\mathrm{km}^{2}$ in area [1]. It is therefore not surprising that it provides critical ecosystem services such as water, food and energy that benefit and support the livelihoods of over 240 million people both within the region and in downstream areas. Of these 10 rivers, the Brahmaputra basin is one of the world's largest and most populated, with a transboundary drainage area of $528,083 \mathrm{~km}^{2}$ [2].

\section{Context}

The Brahmaputra river system, including its tributaries, provides a lifeline for millions of people. On the one hand, it has sustained a plethora of ecosystems, human societies, and cultures in South Asia for thousands of years, contributing to the survival and flourishing of national economies of four basin countries. On the other hand, the river generates catastrophic floods leading to the loss of riparian landmass every year, affecting the lives and livelihoods of millions of people, and the region's economy, infrastructure, and environment. Besides, climate change is exacerbating various natural and socioeconomic process and impacting the basin dwellers, who are expected to face more floods-initially due to accelerated melting of glaciers and consequences of drying rivers carrying less discharge $[3,4]$ and significant changes in the water regime, and socioeconomic, agricultural, food, and energy scenarios $[5,6]$. 
To ensure the sustainability of the Brahmaputra river basin and improve the quality of lives and livelihoods of its communities, all basin countries should have relevant nationallevel policies, a coherent and cooperative basin-level integrated management plan, and a robust knowledge base of future scenarios built around ongoing and anticipated changes in the basin's natural, socioeconomic, and development systems.

The Brahmaputra, which originates in the Chemayungdung glacier in the Kailash range in the south of the Tibet Autonomous Region (at a $5300 \mathrm{~m}$ elevation), traverses China (for a distance of $1625 \mathrm{~km}$ ), India (for $918 \mathrm{~km}$ ), and Bangladesh (for $337 \mathrm{~km}$, where it is called Jamuna). It merges with the Ganges (Padma) and then with the Meghna in Bangladesh, and eventually flows into the Bay of Bengal. The Brahmaputra river basin (BRB) is based within China (50.5\%), India (33.6\%), Bangladesh (8.1\%), and Bhutan (7.8\%) which shows in Figure 1 [7]. The physiographic characteristics of the terrain through which the river flows change drastically, from the Tibetan Plateau to the river valleys of India, to the deltas of the Bay of Bengal in Bangladesh.

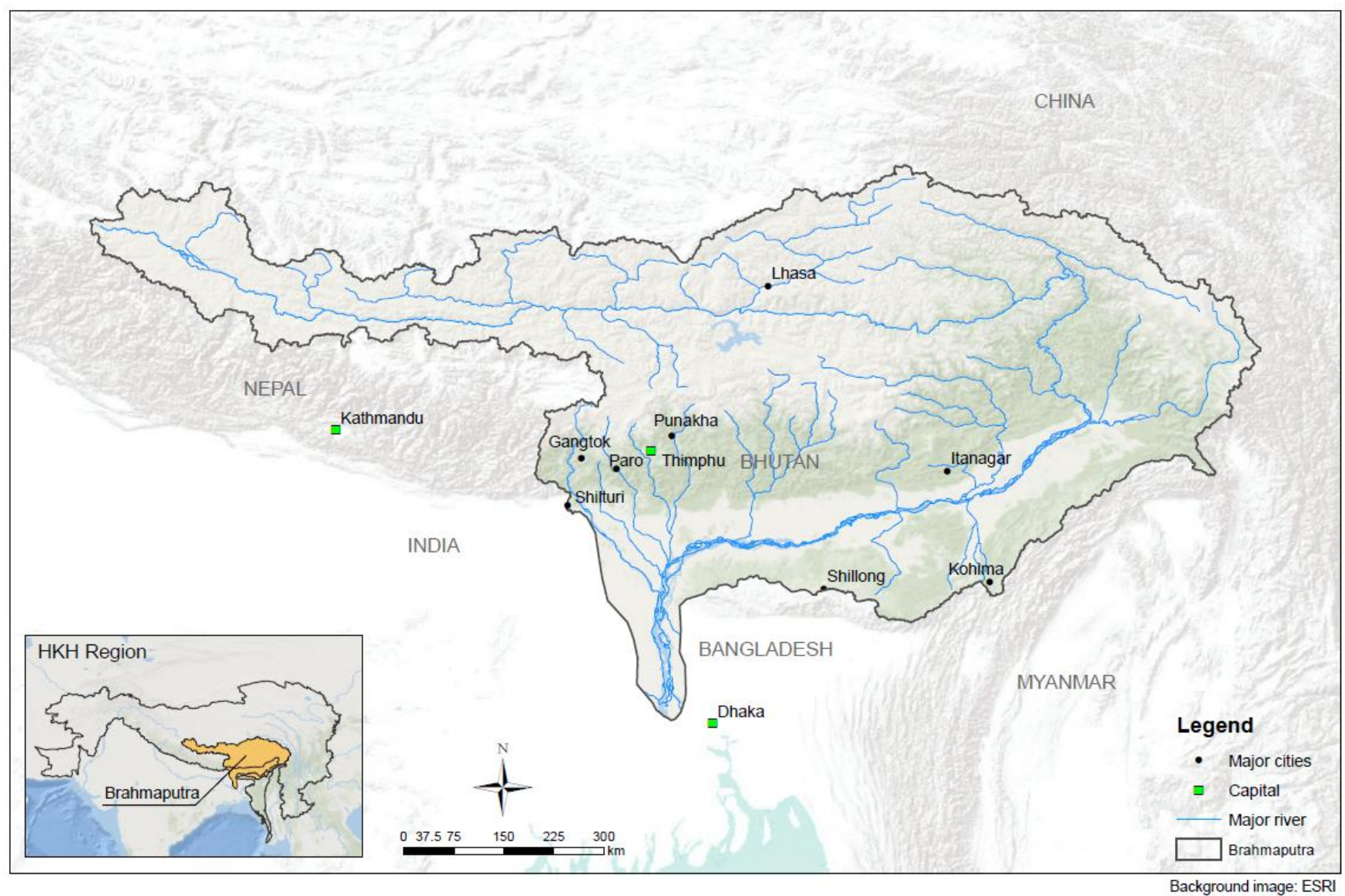

Figure 1. The Brahmaputra river basin. Source: International Centre for Integrated Mountain Development (ICIMOD) 2020.

The Brahmaputra ranks the fourth largest river in the world regarding discharge at the mouth, and second among the rivers transporting the heaviest sediment load [8]. The basin is dominated by rainfall runoff along with a modest contribution from meltwater from the glacial and snowmelt from the areas of the upper basin lying at high altitudes [9]. The Brahmaputra River is the lifeline for community livelihoods and food security in India. Not only is the agricultural sector within the basin heavily dependent on the river's water for irrigation, it contributes to almost $17 \%$ of the gross domestic product (GDP) of India [10]. The socioeconomic benefits that the river provides can be broadly classified as fisheries and ecosystem services. Among the latter are water for domestic use, navigation, irrigation, wetlands, wildlife areas, tourism, and hydropower for 68.07 million people as 
of 2015 within the countries it traverses [2]. The river also transports soil and nutrients to downstream floodplains in addition to contributing to fisheries and agricultural production of the inhabitants, thereby supporting the livelihoods of millions of people.

\subsection{Hydrologic and Geomorphic Regime}

The Brahmaputra's hydrological regime responds to two principal determinants: the seasonal cycles of the monsoons and freeze-thaw cycle of the Himalayan snow. Its flow is both extremely large and variable, and sediment discharge rates are substantially high. It is characterized by rapid channel aggradation and basin denudation and distinctive patterns of dynamic river morphology [11].

The Brahmaputra is the fourth largest river in the world in terms of mean annual discharge, with $33,600 \mathrm{~m}^{3} / \mathrm{s}$ at its mouth [12]. The water yield per unit discharge area $\left(0.0306 \mathrm{~m}^{3} / \mathrm{s} / \mathrm{km}^{2}\right)$ in Pandu (Assam, India) makes Brahmaputra number one among major rivers of the world. The same is true of its tributaries such as Subansiri, Jia Bhoroli, and Manas. The yields of these rivers are as high as $0.076,0.086$ and $0.023 \mathrm{~m}^{3} / \mathrm{s} / \mathrm{km}^{2}$, respectively, which are higher than those of many other great rivers of the world [13]. Among the important determinants of these large unit discharge rates is the high monsoonal precipitation in the upper catchment and the steep slopes. The same factors also play a role in triggering the heavy sediment yield and have been identified as a leading cause of drainage congestion in the valleys [14].

Seasonality and high variability are noteworthy features of the Brahmaputra's flows. For example, while the highest recorded daily discharge at Pandu was $72,794 \mathrm{~m}^{3} / \mathrm{s}$ on 23 August 1962, the lowest was $1757 \mathrm{~m}^{3} / \mathrm{s}$ on 22 February 1968. Moreover, the high summer flows and low winter flows, fluctuate on average 12 times. In some years, a high flow 20 times the value of the low flow has been recorded [15]. In Pandu, Assam, while the average discharge annually is roughly $20,000 \mathrm{~m}^{3} / \mathrm{s}$, the average discharge during the lean season is $4420 \mathrm{~m}^{3} / \mathrm{s}$. In Bahadurabad, Bangladesh (where the Brahmaputra is joined by the Teesta but before it joins the Ganga (Ganges) to flow further downstream as the Padma), the average monsoon (June-October) flow is $35,712.5 \mathrm{~m}^{3} / \mathrm{s}$, whereas the average lean season (January-April) flow is $5186 \mathrm{~m}^{3} / \mathrm{s}$ [16].

The recurrence interval for the river's mean annual flood, which is recorded at $48,200 \mathrm{~m}^{3} / \mathrm{s}$, is reported at 2.2 years. However, On the other hand the likelihood of recurrence of its maximum flood, recorded at $72,726 \mathrm{~m}^{3} / \mathrm{s}$, is comparatively very low at roughly every 133 years [14]. A noteworthy characteristic of the river's flow regime is the significantly large variations in its daily discharge in different seasons. This is the result of the variations in the time-lags and peaking attributes of the flood flows of the different tributaries that drain into the Brahmaputra. Given the differences in catchment physiography and monsoonal rainfall, the changes caused in the characteristics of the Brahmaputra's discharge hydrograph by the tributary's inflows are both enormous and variable [14].

\subsection{Precipitation: Historical and Projected}

The average annual precipitation of the Brahmaputra basin is approximately $1100 \mathrm{~mm}$. It receives over $70 \%$ of this rainfall during the monsoonal season (June-October). A stark contrast is evident between the upper and lower basins, with the lower basin receiving almost three times more rainfall than the upper basin [17]. Studies on past precipitation trends did not find significant trends in rainfall in the basin (1951-1980 and 1981-2007) but found a small increase in average and extreme rainfall in the eastern basin which shows in Figure 2 [3,17]. However, that there was a slight increase in annual and seasonal rainfall between 1961 and 2005, although it was not statistically significant [18]. In contrast, a report also showed an increasing trend in the summer monsoons during the 1990-2000 period [19]. 


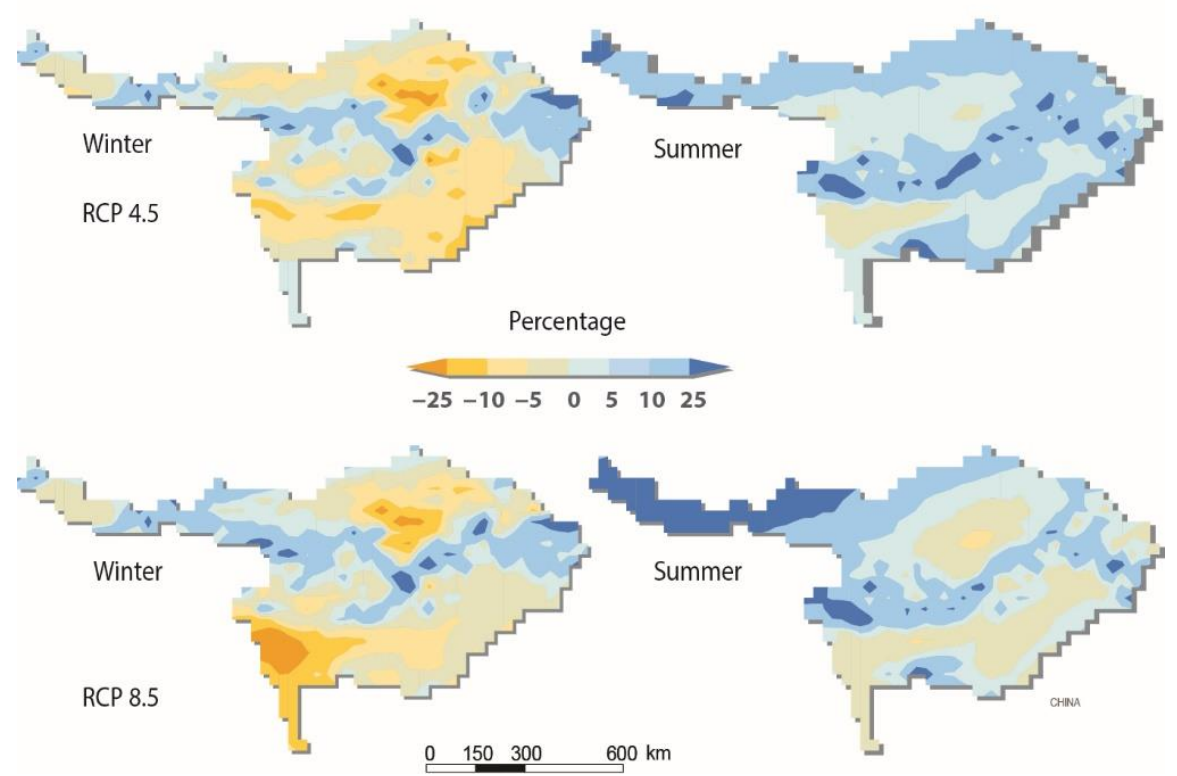

Figure 2. Change in future precipitation (2021-2050) compared with the base period (1961-1990). Scheme 2015. Representative Concentration Pathway (RCP). A Representative Concentration Pathway $(\mathrm{RCP})$ is a greenhouse gas concentration trajectory adopted by the IPCC [20].

Precipitation is projected to increase in the future-both in terms of the total and the extremes, but with strong spatial and seasonal differences. A precipitation increase of about $10 \%$ in the monsoon season was projected by the middle of this century compared with the 1961-1990 period, while winter precipitation in the southwest and the central northern part was projected to decrease $[17,21]$. Likewise, a monsoon shift from July to August was projected in comparison with the 1988-2010 period [22]. An increase in annual rainfall by $56 \%$ and extremes by $104 \%$ towards the latter part of the 21 st century was projected in comparison with the 1981-2010 period [23]. In combination, these studies suggest that there will be more water available during the wet season, which could lead to larger and more frequent floods in some areas and decreased water availability during the dry season. Precipitation distribution and changes can be quite heterogeneous. Limited observations and the coarseness in future projects limit our understanding of what is happening and could occur at micro scales, which is highly important for adaptation planning.

\subsection{Temperature: Historical and Projected}

The basin has experienced an increasing trend in temperature. The warming was highest in winter $\left(+0.5^{\circ} \mathrm{C}\right)$ and lowest in the pre-monsoon season $\left(+0.3^{\circ} \mathrm{C}\right)$ between 1951 and 1980, and 1981 and 2007. However, the change in summer temperature is not significant. Moreover, while an increase in extreme temperatures (the highest maximum) has been observed in the northern parts (the Tibetan Plateau), it has been decreasing in the east and southwards. Meanwhile, a decrease in extreme minimum temperature has also been observed in the center of the basin [17]. It was also reported that $10 \%$ of the warmest years occurred between 1995 and 2002 [3,18].

Studies project further intensifications in warming in future, particularly in the upper parts of the basin in the Tibetan Plateau [3]. They contain some indications of warming based on elevation. According to these projections, the annual temperature will increase by between $1{ }^{\circ} \mathrm{C}$ and $3{ }^{\circ} \mathrm{C}$ by the middle of the century (2050) under moderate greenhouse gas concentration trajectory known as Representative Concentration Pathway 4.5 (RCP 4.5) and extreme Representative Concentration Pathway 8.5 (RCP 8.5) [20], with the northern part of the basin projected to warm more prominently. Higher increases are projected for winter 
temperatures over a significant portion of the basin with some areas projected to see an increase in temperature by more than $3{ }^{\circ} \mathrm{C}$ for RCP 8.5 as compared to 1961-1990 ) (Figure 3) [17]. A similar result was obtained projecting more warming in the higher altitudes and the highest increase in maximum temperature by 2100 as compared to 1971-2000. It was also projected that the average temperature will increase with higher projected values for the Tibetan Plateau under the $1.5{ }^{\circ} \mathrm{C}$ and $2{ }^{\circ} \mathrm{C}$ global average warming scenarios [21,23].

Change in average temperature, 2021-2050

baseline 1961-1990
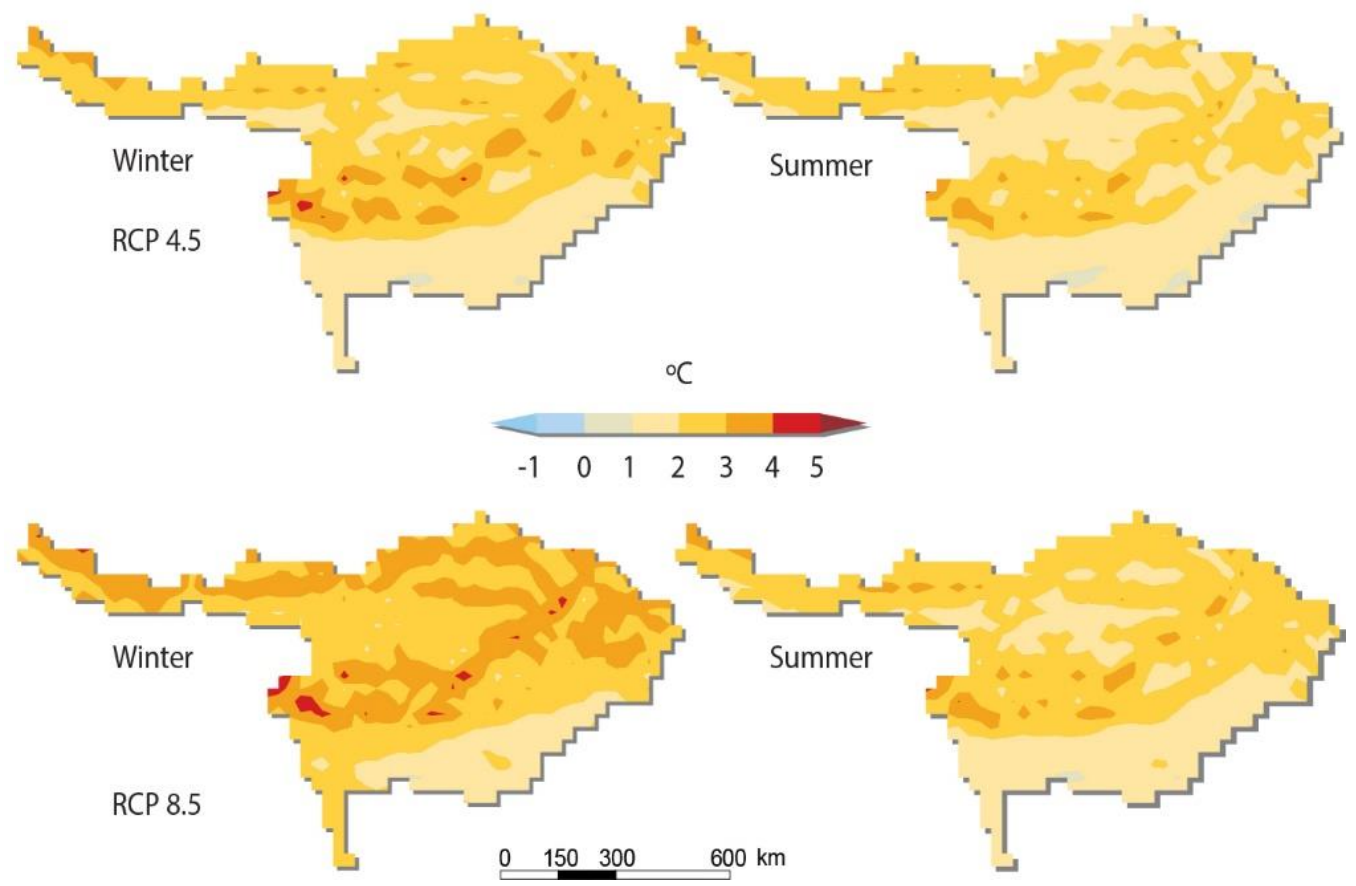

Figure 3. Change in future average temperature (2021-2050) when compared with the base period (1961-1990). Source: Shrestha et al., 2015.

These studies corroborate that there could be enhanced melting of snow and ice in high altitudes, which could then reduce the storage needed for the slow release of water during the dry period and contribute to water scarcity.

\subsection{Biodiversity Hotspot}

The Brahmaputra river basin, one of the most important basins in Asia, is known for its extraordinary biodiversity because of its large variation in endemic flora and fauna and provides livelihood support for inhabitants of the basin [9]. The Brahmaputra river basin (BRB) of the northeastern (NE) Indian region is a part of two biodiversity hotspots-the Himalaya and the Indo-Burma, which are two of 34 such hotspots of mega biodiversity on the planet recognized by the World Conservation Union (IUCN) [24]. The region has considerable diversity in terms of flora and fauna, and their exceptional variation in distribution both vertically and horizontally. The IUCN Red List of Threatened Species 2020 has listed approximately 600 plant species from NE India as rare, endangered, or threatened. More than 800 species of orchids from the region are also included in Appendix-II of the Convention on International Trade in Endangered Species (CITES) and are among those regarded/listed as endangered. The region is also home to 7233 animal species, among them, 195 mammalians, 607 birds, 115 reptiles, 54 amphibians, 267 fish and 4953 insect species. Of these species, 67 (32 mammalians, 28 birds, 6 reptiles and 1 amphibian) are identified as endangered. The northeastern region of India is exceptionally rich in freshwater biodiversity [25] in addition to being a hotspot of freshwater fish biodiversity [26]. 
Among the factors that make northeast India one of the world's richest repositories of faunal resources is the abundance of rivers and floodplain wetlands that provide suitable micro-habitats enriched with a high diversity of biotic and abiotic components which are also favored by suitable climatic conditions [27].

To date, 267 fish species belonging to 114 genera under 38 families and 10 orders have been reported from northeast India, which constitute roughly $33.13 \%$ of the total freshwater fish of India [27,28]. 422 fish species that belong to 133 genera and 38 families are listed from the region and adjoining areas that originate from the Himalayan and Indo-Burma biodiversity hotspot areas [29]. The Brahmaputra river is home to more than 300 species of fish and megafauna, most notably among them being the endangered Gangetic dolphin (Platanista gangetica) [30]. The Assam stretch of the Brahmaputra river is also home to 141 finfish species that are classified under 84 genera and 29 families [31].

A survey conducted of the wintering waterbird community in the Yarlung Zangbo river valley of Tibet generated 33 species and 90,407 individuals in total in January 2009, and 24 species and 95,106 individuals in January 2014. Of the total waterbird count, over $90 \%$ were geese and ducks, while a total of 5558 black-necked cranes were counted in 2014 [32].

\subsection{Socioeconomic Scenario}

The Brahmaputra basin sustains a population of more than 80 million people, comprising more than 200 indigenous, multi-ethnic communities with an average density of 182 persons $/ \mathrm{km}^{2}$. About $97 \%$ (78 million) of the total population of the river basin live in India and Bangladesh-two of the most populous countries in South Asia. The density varies from as high as 828 persons $/ \mathrm{km}^{2}$ in Bangladesh to 143 persons $/ \mathrm{km}^{2}$ in India, 26 persons $/ \mathrm{km}^{2}$ in Bhutan and 6 persons $/ \mathrm{km}^{2}$ in the Tibetan area of China [33]. Of an estimated population of 30 million residing in the Indian part of the basin, the population density, both urban and rural, in the alluvial Brahmaputra Valley is 303 persons $/ \mathrm{km}^{2}$ and 257 persons $/ \mathrm{km}^{2}$, respectively [34].

Topography and local climate are the main determinants of various types of livelihoods, especially agriculture. Therefore, agriculture in the BRB is characterized by a wide range of farming practices and cropping patterns, determined by the various topographic, geoclimatic, agroclimatic and agro-ecological zones of the region. In the high mountain region of Tibet (China), Bhutan and India (Sikkim and Arunachal Pradesh), people sustain their lives mainly on pastoralism, based on livestock rearing, for example, sheep and yak, for their milk products. In the lower mountain zones of India (Arunachal Pradesh and Sikkim) and Bhutan, mixed agro-pastoralist practices such as agriculture, agroforestry, and the rearing of sheep and yak for their milk products are the principal sources of livelihood. Animal husbandry, agriculture and agroforestry are the main livelihood sources in the midand low-altitude hills of India (Sikkim, West Bengal, Assam, Arunachal Pradesh, Nagaland, and Meghalaya), where rice, maize, cereals, potatoes, vegetables, fruits, spices and milk production are the main sources of income and food security [35,36]. Shifting cultivation practices by local indigenous tribes are also rampant in such geographies. The valleys and floodplains in India (Assam and West Bengal) and Bangladesh experience intense agriculture, pisciculture, livestock rearing (mainly cattle, goat, poultry, and pig) and dairy. Riverine (boat-based) transport and floriculture are also livelihoods of some rural people. Jute, oilseeds, sugarcane, tobacco, tea, black pepper, and cardamom are important cash crops in Assam.

The Eastern Himalayan Region is home to over 50 important tropical and subtropical fruits, cereals, and rice [35]. The northeast Indian region is rich in diverse horticultural resources such as fruits, vegetables, flowers (mainly orchids), spices, bamboo, and medicinal and aromatic plants, which carry high potential for economic prosperity of the region [37]. Regarding commercial fruits of the country, citrus, bananas, and jackfruit are the most common to be found in many varieties in northeast India. 
A majority of people especially living in rural areas of the Brahmaputra river valley in Assam depend on the rivers, wetlands, and riverine and aquatic ecosystem services and resources, directly or indirectly, to sustain their livelihoods and to fulfill basic needs of food, nutrition, livestock rearing, housing, and transport. Agriculture and aquaculture are the two main livelihoods of the people in the valley, while paddy is the staple crop and rice is the main cereal. The principal crops cultivated in the various agro-climatic and agro-ecological zones are rice, mustard, sugarcane, jute, pulses, and maize. With roughly $10.5 \%\left(8251 \mathrm{~km}^{2}\right)$ of the geographical area of Assam $\left(78,523 \mathrm{~km}^{2}\right)$ occupied by surface water bodies that include rivers $\left(6503 \mathrm{~km}^{2}\right)$, wetlands and other water bodies that are larger than $0.025 \mathrm{~km}^{2}\left(1748 \mathrm{~km}^{2}\right)$, the state of Assam possesses very high potential for a thriving fishbased economy and aquacultural development. Currently, the state has a shortfall of fish production (0.294 million tons) compared to the demand (0.336 million tons). However, the state has made significant progress in fish production from 0.190 million tons in 2007-2008 to 0.306 million tons in 2016-2017, which is equivalent to a 1.58 -fold rise, and is higher than the increase recorded for India during the same period of time [38].

\subsection{Policy and Institution}

In managing the river, each basin country follows its own set of national and subnational policies-designed to meet their development needs. National climate change adaptation policies are either already in place or being developed in the basin countries. Similarly, most countries are preparing their national adaptation plans (NAPs), and the least developed countries (LDCs) already have their national adaptation programs of action (NAPAs). Analyses show that significant differences exist among the water policies adopted by the basin countries, and they pay attention to adaptation measures related to climate change and climate-induced hazards. A multilateral basin-level institution and a trans-national water management protocol or political agreement are needed to garner regional cooperation for basin management, equitable benefit sharing, and inclusive development. This is especially urgent for the lower riparian nations-India, Bhutan, and Bangladesh—where most of the poor, marginalized, and vulnerable live [5].

\section{Issues and Challenges}

\subsection{River Connectivity}

The significance of river connectivity-longitudinal (river channel), lateral (floodplains), vertical (groundwater and atmosphere), and temporal (intermittency)—in order to ensure linkages between upstream and downstream, regulation of flow, supply of ecosystem services, and preservation of biodiversity has been recognized by the Brisbane Declaration which called for identifying and conserving "a global network of free-flowing rivers (FFRs)". Under Target 6.6 of the United Nations Sustainable Development Goals (2015), the world's governments have committed to "protect and restore water-related ecosystems". Despite these government commitments, only $37 \%$ of rivers longer than $1000 \mathrm{~km}$ (of the 12 million $\mathrm{km}$ of rivers in the world that have been assessed) remain free-flowing from start to finish, and only $23 \%$ reach the ocean unhindered [39]. Of those rivers around the world that can be classified as non-FFRs, $542,000 \mathrm{~km}$ of river reaches are seen to have "good connectivity status" with values on the connectivity status index (CSI) $\geq 95 \%$. Those with 98 contiguous river stretches longer than $500 \mathrm{~km}$ are labeled thus, among which are major segments of the Brahmaputra (India and Bangladesh), Orinoco (Venezuela and Colombia) and Amur (Russia) [39].

There are no structures that obstruct the longitudinal flow of the primary channel of the Brahmaputra inside Indian territory. However, the river is no longer free flowing in China because of several dams that have been constructed as part of hydroelectric projects (HEPs) which are either operational or under construction. China has declared that it will be starting work on a major hydropower project on the Yarlung Zangbo River in the Tibet Autonomous Region near its border with India. A proposal has been put forward in its 
14th Five-Year Plan, which, if implemented, will be bigger than the Three Gorges power station on the Yangtze river in Hubei province [40].

While the Zangmu HEP (510 MW) has been functioning since 2015, the construction of the Jiacha (also called Gyatsa) HEP (320 MW) has been completed and is awaiting commission. Two other dams, the Dagu HEP (640 MW) and the Jeixu HEP (510 MW), are under construction. Some other dams that are being planned, such as Bayu Dam (710 MW) and the Zhongyu Dam (800 MW), are even larger. Some more are on the drawing boards, namely, Pagsum, Langsai, Nyang, Jiexi, Langta, Dakpa, Nang, Demo, Namcha, Metok Zhongda and Langzhen [41-43]. All these projects have, as claimed by China, run-of-river (RoR) schemes, although several dams, such as Dagu and Zangmu, are said to have a large storage capacity. Nevertheless, RoR schemes can have significant environmental impacts downstream in terms of reduced flow, flow velocity, and lower water temperature leading to the loss of riparian vegetation and harm to aquatic fauna, especially fish [44]. Conveyance of local community boats, boat transport, recreational tourism (angling and rafting) and commercial navigation as well as other human and animal uses of rivers are also affected by such situations, sometimes leading to loss of human life as well as wildlife [45].

\subsection{Conflicts of Interest}

The Brahmaputra river can also be said to flow through some of the most disputed areas in South Asia. Hence, the situation is ripe for riparian conflicts of interest relating to the development of water resources. Although its water resources have remained comparatively undeveloped, conflicts of interest are emerging over objections by states downstream to the planned water development projects of states upstream. In the Brahmaputra river basin, there are currently ten dams with a combined hydropower generating capacity of six gigawatts $(\mathrm{GW})$ being constructed. China and India are already exploring the possible transboundary impacts of water diversions. Bhutan is partnering with India to rapidly develop its hydropower resources. Bangladesh is keen not only to secure water for irrigation for agricultural purposes, but also to ensure better protection against the ubiquitous seasonal floods of the monsoons [6].

\subsection{Anthropogenic Stressors}

Despite its multiple uses and benefits, the Brahmaputra basin continues to face various anthropogenic stressors associated with a growing human population (among them, land-use change, increased water pollution, demands for water, and channelization and regulation of river flows) which negatively affect the basin. Compounding these issues are variations in seasonal temperature and precipitation patterns with increased variability in rainfall resulting in extremes such as floods and droughts [46] and fluctuations in the volume of meltwater potentially influenced by climate change. Such phenomena could place further pressure on this already strained basin. Population growth, coupled with such climate change variability, pose risks to food security and livelihoods of large numbers of people in the region. These issues emphasize the urgency of implementing sustainable solutions [9].

\subsection{Regional Cooperation}

The Brahmaputra basin countries are all parties to various initiatives on international cooperation on climate change. In the nationally determined contributions (NDCs) of the respective countries, adaptations in the water sector are well addressed. Hence, cooperation at regional level should be considered vitally important in the basin, because many climate change-related impacts are cross-border in nature. Nevertheless, there is little effort at collaborating and cooperating in the generating and sharing of scientific data among the countries in the region. A similar situation prevails relating to collaboration between communities upstream and downstream, as well as across borders. These issues undoubtedly require urgent attention [47]. 
Development interventions, especially the structural measures for disaster management, irrigation, and power production, have disturbed riverine connectivity, constraining the Brahmaputra's ability to deliver ecological functions and services. In the absence of any basin-level mechanism of collaboration, national policies are often disjointed and sometimes contradictory when evaluated in the context of integrated basin management. A lack of joint efforts for water resource development and benefit sharing among the basin countries has led to disputes and conflicts over water sharing, disaster management, ecohydrological degradation, and environmental impact. Cooperation among upstream and downstream countries and coherence in their policies for utilizing the river for development purposes is a precondition for regional collaboration in transboundary river co-management.

Resource management in the entire basin, coupled with increased conflicts over trade-offs relating to resource utilization, is a matter of paramount importance when it comes to the sustainable management of the Brahmaputra [36]. Better governance and an institutional mechanism are a challenge in the basin due to disharmonized relationships between the basin countries and actors. The political and transboundary conflict in the Teesta, one of the tributaries of the Brahmaputra, is leading to the drying-up of channels in Bangladesh and the diversion of water from the Teesta through canals into other rivers such as the Mahananda, Dauk and Nagar, which cater to the irrigation and drinking water needs of communities in Jalpaiguri and Siliguri in India [48].

\section{Multi-Hazard Scenario and Its Impacts on Riverine Ecosystem}

\subsection{Water and Climate Induced Hazards}

Floods are recurring events in the Brahmaputra basin. During the monsoon season that falls between June and October, there are floods leading to death and destruction in both India and Bangladesh [49]. It is predicted that a considerable rise in mean peak discharge in the Brahmaputra river based on scenarios of climate change from four Global Circulation Models (GCMs) would result in more frequent floods [50,51]. One reason for the rise in river flow in the upper parts of the basin is increases in rainfall extremes under climate change [4]. The flow variations will also increase considerably towards the latter part of the century, thereby indicating an increase in extreme flows [23]. It is predicted that extreme low flow conditions will not be as frequent an occurrence in the future as they are now [52]. On the other hand, more frequent flood events of low magnitude are projected to increase [53], which could be regarded as positive for the riverine ecosystem. In contrast, the projected increase in peak flow and high intensity floods could be challenging both from an ecosystem as well as infrastructure and society perspective.

People living in the lower Brahmaputra river basin that encompasses India and Bangladesh are at a high risk to various types of water- and climate-induced disasters, among them, floods, the eroding of riverbanks, and degradation of land due to excessive sand and silt deposition and droughts as well as the unpredictability and changing nature of these disasters. The most serious among them are floods and erosion of riverbanks. These affect millions of people, albeit differently. In addition, the economic loss and damage to the two countries is huge from these natural disasters that are becoming ever more intense, frequent, and unpredictable in a changing climate.

The Brahmaputra valley of Assam is considered one of the most acutely flood-prone regions in India, with $40 \%$ of the land surface prone to floods, which is one of the largest among all Indian states, constituting 9.4\% of India's total flood prone areas [8]. Over $90 \%$ of the land encompasses agriculture, as well as urban population centers. It also includes the state's valuable economic assets, among them, tea estates, oil fields, roads, and airports. The Brahmaputra and its tributaries cause flooding in Assam every year. On more than fifteen occasions, the annual floods were of catastrophic proportions in the post-1950 earthquake period-1954, 1962, 1966, 1968, 1972, 1977, 1984, 1986, 1987, 1988, 1998, 2002, 2004, 2008 and 2012 and 2017 and 2020. 
Floods have caused considerable damage to life and property of humans as well as agriculture and the environment, and the overall damage to the economy of the state is thus extensive. On average, floods affect about 5.0 million people, $10,000 \mathrm{~km}^{2}$ of agricultural and non-agricultural land, with damage of about USD 100 million [54,55]. It was estimated that the damage by floods in Assam on average per year for the 1953-2011 period are as follows: $8580 \mathrm{~km}^{2}$ of land; $>2.5$ million people; and $>77,000$ households [56]. During some years, floods have affected over $38,000 \mathrm{~km}^{2}$ out of the total land extent of $78,000 \mathrm{~km}^{2}$ in Assam [10].

In the aftermath of the great earthquake of 1950, the severity, recurrence, and the destruction due to floods increased gradually. Among the floods that are considered the most destructive in the recent history of Assam are those of 1988, 1998, 2004, 2012 and 2017. Of these, the 1988 floods are considered the worst in terms of recorded flood damage. Besides causing the deaths of 226 people and innumerable cattle and wildlife, it affected $38,200 \mathrm{~km}^{2}$ of land, nearly 12 million people, 0.5 million households and $14,300 \mathrm{~km}^{2}$ of cropland. USD 1086 million was the estimated total damage from the flood. In terms of inundation and the persistence of flood conditions, the 1998 floods were most severe, with many gauge stations recording some of their highest flood levels. The estimated total loss was given at USD 242 million. When nearly all the Brahmaputra valley was inundated in 2002, the loss was estimated at USD 411 million [8]. This is the reason why Assam is considered the second-most disaster-prone state of India [57].

In Bangladesh, the cost of the destruction caused by the 1988 floods was estimated at approximately USD 2 billion, with the number of people directly affected being approximately 45 million. The cost of direct damage from the 1998 flood was calculated as USD 2.8 billion. It was calculated at USD 2 billion for the destruction caused by the 2004 flood. In Bangladesh, the Brahmaputra (locally called Jamuna) remains the major cause of flood-related calamities. The river reportedly burst its banks twice in 2007, leading to the deaths of 600 people and destruction of crops in roughly 39 of Bangladesh's 64 districts [58]. There are many studies which suggest that riverbank erosion in roughly $2000 \mathrm{~km}$ of river reaches in Bangladesh each year is mainly due to flow processes triggered by floods. They have shown that the Brahmaputra (Jamuna) river in Bangladesh records the highest rate of erosion. It was identified as the cause of erosion of roughly $880 \mathrm{~km}^{2}$ of land during 1973-2004, resulting in more than 0.9 million people becoming homeless and landless [59].

Riverbank erosion is a chronic problem in Assam as well, due to the dynamic shifting of channels flowing through unconsolidated heavy sand or silt strata of the floodplain with high sediment discharge. During the 1954-2011 period, Assam's seventeen riverine districts lost nearly $7 \%$ of their land area due to erosion. Moreover, it is estimated that roughly $80 \mathrm{~km}^{2}$ of land (valued at USD 20 million) is lost every year. In addition, both floods and erosion cause the displacement of roughly 10,000 families annually, many of whom consequently become landless with its attendant social and economic problems [55,60].

\subsection{Sediment Dynamics and River Connectivity}

A river can maintain its health and deliver its ecosystem services provided that its three-dimensional connectivity is conserved: longitudinally, from headwaters to confluences and the sea; laterally, from the main channel to the floodplains on both sides of the river; and vertically, from the river vertically down towards the hyporheic interstitial and the groundwater. This spatial connectivity makes the transportation of matter and energy by a river possible, as well as the dispersion of organisms [61].

It is well known that river connectivity is changed, reduced and, sometimes, completely halted by various structures such as dams, barrages and embankments erected on rivers for various purposes. For example, dams and reservoirs are built to generate hydropower and facilitate irrigation, navigation, water supply and flood moderation. Barrages help in diverting and allocating water to different areas for irrigation. Embankments, on the other hand, are constructed on riverbanks mainly for flood control. While dams, reservoirs and barrages affect longitudinal flow and connectivity of rivers, the embank- 
ments obstruct lateral flow and connectivity. Thus, these structures can be harmful to the ecohydrological regime of rivers.

When reservoirs trap sediment in the upstream of rivers along with water, the continuity of sediment transport is disturbed, and channel forms and aquatic habitats are affected in the downstream stretches [62]. Furthermore, downstream areas are deprived of the nutrients that spill over with sediment to the floodplains and riparian agricultural areas during flooding, which results in the reduction in the fertility of soil and crop production. Sediment loss in reservoirs also affects the channel forms and aquatic habitats. Dams and reservoirs can also artificially regulate the eco-hydrological conditions and processes. They change the riverine ecosystems through abiotic and biotic impacts [63], such as modification in discharge, water level and temperature regime; changes in the composition of suspended material and nutrient fluxes in the river's system; disruption of life cycles in macro-vertebrates and fish; and migration restrictions for fish [64]. The dams prevent the movement of aquatic fauna such as fish and dolphins along the river from upstream to downstream and vice versa as part of the process of their normal survival and breeding.

This is more evident in the case of migratory fishes such as the mahseer. The golden mahseer (Tor putitora), for example, is an endangered game fish that has a high value in ecotourism, mainly among anglers, and is present in several tributaries of the Brahmaputra in India such as the Jia Bharali (known as the Kameng in Arunachal Pradesh), Teesta (Sikkim and West Bengal), Manas (Bhutan and Assam) and Subansiri (Assam). The same is true of barrages that divert the flow of a river and transport water to different areas through canals. They allow less water flow downstream compared to the normal flow if unobstructed. Both dams and barrages, depending on the principles and practices of operation of reservoir and gates, can drastically change and reduce the downstream flow so that the ecological and human needs for water as well as the ecosystem services of rivers are compromised. The environmental flow, which is considered an important indicator of ecohydrological health, in controlled rivers (i.e., rivers with structures that control flows) is now gaining ground as a key factor in decision-making about river interventions as well as impact assessments of hydraulic structures on rivers.

Similarly, embankments cut flood plains off from a river and stop the sediment- and nutrient-carrying flood waters from spreading out into the countryside and thereby replenishing the fertility of the farmlands. Embankments are also responsible for obstructing many small natural water ways which used to be connected to the main river, thus causing waterlogging due to congested drainage as well as seepage both across the countryside and between the countryside and the riverside of the embankment. Thus, the natural floodplain undergoes changes in its landscape characteristics through construction of embankments, which often lead to both fragmentation and ecological degradation of the floodplain. It is noteworthy that, with regard to embankments, Assam has the maximum length, approximately $5000 \mathrm{~km}$, among all states of India, and most of them are found on the banks of the Brahmaputra and its tributaries.

\subsection{Tectonic and Flood Hazards}

The Brahmaputra basin in northeast India is in Zone-V, the most active seismic zone in the world [65]. It constitutes, thus, an extremely unstable seismic region that is highly vulnerable to earthquakes. Of the five great earthquakes (with a magnitude $>8$ on the Richter scale) that have struck the planet so far, two have occurred in this region, namely, the Great Assam earthquake of 1897 and the Assam earthquake of 1950, with magnitudes 8.7 and 8.6 on the Richter scale, respectively, resulting in catastrophic damage to landscape, life and property. In addition, several smaller earthquakes have affected different parts of the BRB over the last 100 years.

The effect of tectonic activity on the hydrologic and geomorphic regime of the Brahmaputra river system has been significant. This includes its numerous tributaries and water bodies (i.e., wetlands) that are scattered throughout the flood plains. In the aftermath of the two great earthquakes of 1897 and 1950, flood hazards, for example, have intensified [66]. 
Among the impacts are the following: large-scale landslides and rock-falls on hillslopes; ground subsidence and fissuring in the valley; and changes in the course and configuration of rivers.

The impact of the earthquakes on the hydrologic regime of the region is significant. They have triggered landslides on hillslopes that have resulted at times in obstructions of river courses leading to the formation of naturally dammed lakes, which, when collapsed, have triggered catastrophic flash floods. Riverbeds have been raised because of heavy deposition of sediment, fissuring, and sand venting. The subsidence or elevation of the bottoms of existing rivers and lakes and the creation of new water bodies and waterfalls due to faulting have been described as other examples of hydrological impact of active tectonic processes. The phenomena of denudation of the Himalayas and alluviation of the Brahmaputra valley in Assam are concomitant to tectonic forces [11]. Periods of rapid aggradation of the Brahmaputra channel linked to earthquakes followed by relatively slower removal of accumulated debris over longer periods of time are also observable in the region.

\subsection{Anthropogenic Hazards}

The Brahmaputra river has a multitude of key ecological and societal functions. Among its key functions are soil fertility maintenance, transportation, forest resource generation, and wildlife conservation. It also serves the needs of the industrial, agricultural, and domestic sectors and contains a large fish stock with numerous fish species. However, it continues to face various levels of anthropogenic stressors [9]. Among the stressors are the demand for water, which has been increasing due to population growth and urbanization. Among other stressors are the overexploitation of river resources, pollution of water (at point and nonpoint source), modification of the river flow by blockages and dams, damage to and degradation of riparian habitats, especially of flood plains, posed by the rising demand for land for agricultural and urbanization purposes, and the invasion of exotic fish species. Added to these are environmental changes such as global warming and variations in rainfall patterns. They too play significant roles in threatening the river and its diverse fish population.

An important constituent of the ecosystems of the Brahmaputra river are its fish species. They control the trophic structures that affect the disbursement of nutrients. Some appear at the top of food webs as apex predators while others are treated as indicators of riverine health. One reason that these fish species have come into focus is that they are a vital and, at times, the only protein source for poorer segments of the population. However, like rivers, the survival of freshwater fish too is threatened. They are not just the most endangered group of vertebrates along with amphibians, but have rates of extinction that are five times greater than that of terrestrial animals and three times that of coastal marine mammals. This only emphasizes the importance of protecting the river and its fish.

\section{Sustainable Management Options}

A better understanding of the interactive biophysical and socioeconomic components of river systems is necessary for effective planning based on sustainable management options for healthy rivers and ecosystems. Integrated water resources management (IWRM) is one such approach, and it may be instrumental to developing adaptive management solutions across geographical ranges-from the upstream to the downstream [67]. The implementation of IWRM solutions entails paying special attention to the linkages between upstream areas and downstream regions at macro (river basin), meso (catchment), and micro (local) scales. When a river flows from the upstream (the headwaters) to the downstream (the floodplains), its waters are used by multiple sectors as a resource-in agriculture, hydropower, navigation, industry, and for domestic use [68].

Identifying key environmental assets (e.g., protected areas and culturally or spiritually significant locations, ecosystems or processes, and species), understanding the significance of the services they provide to people (their livelihoods and their quality of life), and 
quantifying the water needs of specific basin populations are some important steps in basin planning to support sustainable management. In basin management, we consider assets such as wetlands and floodplains to be critical habitats and species, and regional and cross-border cooperation is needed which is directly connected to the river network and influences water resource development [68].

\subsection{Transboundary and the Inter-State River and Its Management}

The existing water policies of the Brahmaputra basin countries are adequate to provide multiple benefits to dependent communities if applied at the grassroots level. To ensure better water resource management and control measures, there is the need for a shift in water policies that would promote the participation of local communities. Better management of water will also assist in ensuring the sustainability of the basin conservation plans. As a signatory to the Sendai framework for disaster risk reduction, flood cooperation could substantially strengthen disaster risk reduction and assist in fulfilling the international commitments of respective basin countries.

Transboundary water management has the potential to generate numerous benefits, such as more international trade, promotion of climate change adaptation and resilience, increase in economic growth, promotion of food security, and improvements in governance and regional integration. It is important to pay attention to the management of transboundary waters, because these also affect sustainable development within and beyond a country's borders. The sectors that depend on water resources, such as agriculture, industry, energy, navigation, and water supply and sanitation, should consider cooperation on a supranational level to ensure the creation of a resilient region. To achieve this, it is important to identify and assess the most suitable ways to manage ecosystems and their water requirements in order to balance the complexities arising from the relations between different basin countries [36].

Brahmaputra, being a complex river basin, requires a good governance mechanism which would be key to understanding the ecological, economic and political context, the relationship between the various actors, and the factors affecting current and potential future situations [36]. In order to address the complexity of transboundary governance in the Brahmaputra river, SaciWATERs initiated the Brahmaputra dialogue process in 2013 with the objective of identifying the issues and challenges and to find ways to foster cooperation across the boundaries for better governance. In 2013, SaciWATERs, along with Bangladesh University of Engineering and Technology (BUET), IIT-Guwahati (IIT-G) and The Asia Foundation, therefore, initiated a dialogue between India and Bangladesh [69]. It made a steady contribution towards building collaboration for effective transboundary governance among the riparian nations of China, Bhutan, India, and Bangladesh.

What is required for water diplomacy at various levels in the Brahmaputra river basin are better transboundary cooperation facilitated via a well-established knowledge network, a coordinated approach to capacity building, the formulation of joint adaptation projects, a mechanism for high-level coordination, and the creation of an adaptation portal. The time is clearly right for the basin countries to come together to share, discuss, and devise adaptation strategies that are not only best-suited or tailored for themselves, but also for the region. It is important to view the basin as a single entity, where collaborative and cooperative actions are necessary to enable the region to deal with the negative impacts of climate change, thereby making the region climate-resilient with the capacity to move gradually towards sustainable development [70].

\subsection{Framework Agreement on India-Bangladesh Transboundary Cooperation}

There are signs of collaboration between Bangladesh and India in the field of disaster management and climate change, besides the treaty on sharing the water of the Ganga signed in 1996. An example would be the "Framework Agreement on Cooperation for Development between India and Bangladesh" signed between the two countries on 6 September 2011 [71], which identifies water, disaster, and climate change as important 
areas for cooperation. This framework agreement, if invoked and used effectively, would considerably improve transboundary cooperation on various aspects such as flood management and climate change adaptation [72]. As per Article 2 of the agreement, the two countries have consented to "enhance cooperation in sharing of the waters of common rivers and explore possibilities of common basin management of common rivers for mutual benefit" and "cooperate in flood forecasting and flood control". As per Article 3, they have agreed to "develop mechanisms for technical cooperation and exchange of advanced information with respect to natural disasters" and to "promote training and capacity building initiatives and cooperation between respective disaster management authorities, with a view to upgrading response mechanisms". As per Article 6, they would "develop and implement programs for environmental protection and respond to the challenges of climate change through adaptation".

A system of transmission of flood forecasting data on major rivers such as the Ganga, Teesta, Brahmaputra, and Barak during the monsoon season from India to Bangladesh already exists. The transmission of flood forecasting information during the monsoon has enabled the civil and military authorities in Bangladesh to shift the population affected by floods to safer places [73]. The Statute of the Indo-Bangla Joint Rivers Commission (JRC) was signed by India and Bangladesh on 24 November 1972. This led to the creation of a JRC legally empowered to liaise between the two countries on the following: harnessing shared rivers for equitable mutual benefits of both the countries, and flood forecasting, flood warning, cyclone warning, flood control and irrigation through study, research and the implementation of joint projects [74]. The JRC has not succeeded to the greatest extent in addressing the bilateral issues within its purview, such as finding amicable resolutions for conflicts over water sharing. However, the possibility exists for reforming, restructuring and strengthening it to play a more effective role in promoting and facilitating transboundary water cooperation, especially for the Brahmaputra river, for which there is no instrument of agreement between the two countries at present [59].

A trade agreement was signed between India and Bangladesh on 6 June 2015, to expand areas of cooperation in trade and strengthen economic relations between the two countries based on equality and mutual benefit [75]. In Article VIII of the Agreement, the two countries agreed to make mutually beneficial arrangements for the use of their waterways for commercial purposes allowing transit and passage through their respective territories. As a follow-up to this provision in the agreement, a "Protocol on Inland Water Transit and Trade" was also signed on the same day in 2015 [76], where the two countries committed to maintaining the river routes falling within their respective territories in a navigable condition and carry out all the essential pilotage and conservancy hydrographic surveys. The river routes, as defined in this protocol, include and connect a number of ports on the Brahmaputra-Jamuna river such as Narayanganj, Sirajganj, Bahadurabad and Chilmari on the Bangladesh side and Dhubri, Pandu and Shilghat on the Indian side. Sustaining the navigability of the main stem of the Brahmaputra River in India (918 km) and the Jamuna in Bangladesh ( $337 \mathrm{~km}$ ), as envisaged in this protocol, would substantially contribute towards ensuring the connectivity and free flow of the river in this $1255 \mathrm{~km}$ stretch between India and Bangladesh.

\subsection{Community-Based Flood Early Warning System (CBFEWS)}

A large area of the Brahmaputra basin is inundated every year, leading not only to immense losses in lives and livelihoods, but the displacement of millions of people. According to the Hyogo Protocol and the IPCC (Inter Governmental Panel on Climate Change)'s Special Report on Extreme Events and Disasters (SREX), there are gaps in providing early warning information to the communities that are considered the most vulnerable [77]. The absence of a specific mechanism to alert the downstream communities about the rapid rise of water levels has led to disastrous impacts on the livelihoods of the vulnerable people. 
CBFEWS is a system conceptualized and implemented by the International Centre for Integrated Mountain Development (ICIMOD), jointly with the district disaster management authority (DDMA) in Dhemaji and Lakhimpur and Aaranyak, a local NGO in Assam, India during 2010-2016. It was envisioned to provide near real-time flood information in the river tributaries to the vulnerable communities. It helps to prepare them for the upcoming flood risk. CBFEWS is an integrated system of tools and plans, whereby the upstream communities, upon detecting the water level rise, send the information to vulnerable downstream communities, which will enable them to prepare and respond to the upcoming flood. These early warning messages are disseminated using low-cost technology such as wireless and solar-powered transmitters and receiver stations and mobile phone text messaging [78].

Five CBFEWS instruments were installed in Jiadhal and Singora rivers in Assam in 2013, with the active involvement and ownership of local people and DDMAs, which were able to reach out to 45 vulnerable communities downstream by providing them early flood warnings. Although the cost per instrument was roughly USD 1000, the savings through information dissemination by CBFEWS were estimated at USD 3300 in terms of assets saved in the flood of 5 September 2013, in Dihiri village in Dhimaji District. Its stellar contribution towards disaster preparedness through a novel use of ICT has been recognized at the UNFCCC's Momentum for Change 2014 Lighthouse Activity Award. This recognition made it possible to enhance the CBFEWS instrument from wireless to a telemetry based EWS and to scale it up in different tributaries in Nepal, India, Pakistan, and Afghanistan in the Hindu Kush Himalayan region. The CBFEWS has been replicated in Africa with support from ICIMOD and Sustainable Eco Engineering, a manufacturing partner. There are opportunities to scale out and scale up CBFEWS at cross-border and local levels in the basin countries.

\subsection{Flood-Resilient Infrastructure}

To minimize the loss of lives and livelihoods during the annual floods which adversely impact the communities living along the banks of the Brahmaputra, agencies involved can invest in flood-resilient infrastructures. This would require elevating houses on raised platforms, including provisions for sanitation and the storage of safe drinking water, and protecting kitchen gardens, poultry, and livestock from flood waters. Embankments around such raised constructions can be strengthened by using native plant species to avoid landslides triggered by soil erosion. Such sustainable and climate-resilient practices are already being used in other flood-prone areas of the Ganges floodplains, such as Shariatpur, Munshiganj and Faridpur in Bangladesh, and they can be widely implemented through the training of local-level masons, construction workers, and carpenters [79].

Another practice which could provide great benefits during floods is the Ecological Sanitation (EcoSan) Toilet, which is a self-sustaining sanitation facility, which would be especially beneficial and safe for women during floods. The key benefits of this climateresilient practice are its ability to convert human waste to "humanure", which can be used as fertilizer after being mixed with water. Furthermore, it does not require water for flushing, which would help in saving given the scarcity of fresh water during a flood. The system makes it possible to collect waste overground, thus it prevents the contamination of groundwater, which is a huge challenge within communities during floods [79].

\subsection{Wetland Conservation and Management}

The Brahmaputra valley of Assam, rich in floodplain wetlands of various types, shapes, and sizes, offers essential sources of food and livelihoods. It also provides habitat, natural spawning, and feeding ground for fish and other aquatic and terrestrial wildlife. Wetlands also help in moderating flood levels while hazards regulate sedimentation processes and erosion in the floodplains and rivers. Conversely, wetlands act as water reservoirs retaining water for dry periods and help sustain stream flow [60]. All types of wetlands and the open wetlands that are connected to river courses through inlet and outlet channels are 
dependent on these rivers for sustenance of the ecosystem functions and services. The hydrological connectivity among wetlands and with the rivers are of crucial importance for ecohydrological functioning of both rivers and wetlands.

The wetlands of the BRB region are facing grave threats to their existence, already experiencing shrinkage in area as well as ecological degradation, including, in some cases, the death of some wetlands. Anthropogenic changes may significantly alter the nature of ecosystem structures and functions of the wetlands affecting the people dependent on them for their lives and livelihoods. The main threats to wetlands are rapid urbanization resulting in the conversion of wetland areas to human settlements; encroachment and development of built-up area; degeneration of water quality due to pollution by solid waste and liquid effluents from industrial, municipal and domestic sources; the conversion of wetlands into agricultural areas in rural landscapes; and overexploitation of resources such as fish and macrophytes. Drying of wetlands, both anthropogenic and climate changeinduced, now threatens biodiversity, agricultural productivity, and rural livelihoods across the Tibetan Plateau. The high-altitude wetlands in the Yarlung Zangbo-Brahmaputra river basin in Tibet are projected to be affected by sediment deposition, rendering the wetlands shallow and the formation of higher shoals, thus leading to degradation of the wetland. The habitats and food of fish will shrink, resulting in reduced fish stock in these wetlands, which will adversely impact local livelihoods.

The world's largest riverine island, the Majuli island of Assam, India, is located within the Brahmaputra basin. Hence, it is critical to invest in the capacity-building of existing research agencies and institutions working on the Brahmaputra, both through aid from donor agencies and through governmental support to assist in current efforts to strengthen wetland conservation and management through community involvement, for example, the maintenance of embankments and construction of flood-resistant houses and toilets. Some of the ways through which such efforts can be supported is by bringing the water resource management policies and legislations onto a common platform, keeping in mind the climate change projections for the basin [9].

To begin with, it will be vital to collect individual household level data to understand both the local threats and how they are perceived by the communities. In addition, this will help researchers to understand the extent of dependency of indigenous communities on ecosystem services and livelihood choices. These findings would be critical in promoting sustainable use of available resources at all levels of governance [9].

\subsection{Freshwater Fish Safe Zones}

Given the dire situation of the Brahmaputra river and its biodiversity, innovative measures to protect and manage it is needed. One such measure is identifying and incorporating "freshwater fish safe zones" (FFSZs). They are defined as "river reaches important for biodiversity maintenance and connectivity of a river, protected and conserved through legislative measures and local stakeholders' support" that would function as a supplementary measure which would protect endangered river reaches or fish species that require immediate legislative intervention [80]. However, before introducing FFSZs on the Brahmaputra river, it is important to understand the existing resource use and dependency on the river to devise an integrated management plan. Such a plan should factor in the social and economic needs of residents in relation to the river. Moreover, greater participation of stakeholders from the area in setting up the FFSZs is needed [80]. Such a plan would, however, compete against proposals to safeguard the habitats of focal species in a river system's upstream and downstream catchment. However, such proposals should not become a barrier to the protection of critical fish habitats, because the latter would have extensive benefits in comparison with a situation where no defenses at all are provided. It is possible that FFSZs would not be able to cover an entire catchment basin, but they would still play a critical role in safeguarding spawning grounds, nurseries, refuges, or the migratory routes of various fish species within river reaches that fall within their boundaries [80]. 


\subsection{Disaster Risk Financing}

The Asian Development Bank has committed USD 150 million to deliver crucial infrastructure, such as drains in Dhaka and Khulna city regions, to improve flood resilience, solid waste management, and wellbeing. In addition, a USD 100 million grant is assisting with water supply and sanitation [81]. The World Bank has also approved USD 200 million to improve access to safe water and sanitation services in rural areas of Bangladesh, with an aim of helping 600,000 people obtain safe and clean water through large and small piped water schemes, and to provide access to improved sanitation services for over 3.6 million individuals [82].

The Asian Development Bank has also financed the Assam Integrated Flood and Riverbank Erosion Risk Management Investment Program with USD 120 million since 2010. The Flood and River Erosion Management Agency of Assam (FREMAA), Indiaa society under the Assam Water Resources Department-is the nodal agency for the implementation of the program that is expected to be completed in 2020 [83]. The project aims to improve flood and riverbank erosion management by adopting a community-based approach built around institutional reform and the strengthening of the knowledge base of the water sector. This project is being carried out in three locations, namely, Palasbari-Gumi (Kamrup District), Kaziranga (Golaghat District), and Dibrugarh (Dibrugarh District). The project is working to protect their riverbanks and to construct new robust embankments while strengthening old ones. Besides focusing on efforts to make the selected landscapes flood-proof, the project is involved in building the capacity of agencies and communities in flood risk management and emergency response. The project is helping adopt sustainable adaptation strategies for long-term development benefits [84].

The Assam Water Research and Management Institute Society (AWARMIS), Government of Assam, carried out a project on "flood and erosion management modernization" during 2016-2020, receiving financial support amounting to approximately USD $200 \mathrm{mil}-$ lion. Under the project, the Assam Water Resources Department worked on building infrastructure and on preparing an integrated flood, erosion, and sediment management strategy with a river basin approach [84].

The World Bank has agreed to invest an amount of USD 88 million in the Assam Inland Water Transport Project. The project aims to improve the water transport sector, specifically India's National Waterway (NW)-2 [85], which covers a section of the Brahmaputra and the entire length of the Lohit River, which is a major tributary that flows into Assam from eastern Arunachal Pradesh. The NW-2 is the second most important riverine route in India, where Assam has more than 350 networks of navigable waterways. The mandate of this project is to make the river transport system in the state modern, efficient, safe, and capable of handling large volumes of passengers and cargo while creating state-of-the-art river ports. This project is expected to contribute to development, the strengthening of local and state economies by boosting riverine trade and transport, and improving local connectivity and the mobility of riverine communities. It is also expected to enhance safety and security, and the comfort of passengers, especially those living on the state's remote islands (known locally as chars). Moreover, river transport has a relatively high sustainability value because its carbon footprint and environmental impacts are low in comparison to surface transport. It is also a comparatively low-cost option. These anticipated achievements will help reduce risk and enhance resilience and socioeconomic development in Assam.

\section{Emerging Challenges in the Basin}

There is inadequate understanding of future scenarios of the Brahmaputra river basin encompassing its physical, climatic, ecological, and social regimes. The information generated is sporadic, however the available information-based on various projections about climate change and probable development interventions-helps portray a plausible future of the basin.

The mismatch between water supply and demand leads to water challenges. Although changes in glacier melt, rainfall, evaporation, and other attributes determining 
water balance can bring about related changes in water availability, demographics and agricultural practices among other factors determine changes in consumption patterns. The current and projected changes in temperature, rainfall, and extreme climate scenarios pose challenges to residents, particularly in relation to water demand and supply, and agriculture, which is directly affected by any change in water availability due to climate change. This will in turn affect food security, drinking water supply, and human health. Beyond these effects, the indirect impacts on ecosystem functioning, including forests and wetlands and the numerous services they provide, cannot be overlooked [47].

A common future projected for the basin is a general enhancement in streamflow [86] and a consequent increase in the magnitude and frequency of flooding [87]. Concerted measures aimed at disaster risk reduction at the national and transboundary levels will be necessary. The basin is estimated to experience a $40 \%$ increase in annual sediment load by the end of this century (2075-2100) compared to what it was during 1986-1991 [88]. This will have remarkable bearings on aquatic ecology, agriculture, energy (hydroelectric) generation, and water storage (in reservoirs) for irrigation and drinking. Water scarcity in this apparently water-rich basin will increase in the dry season-during NovemberMay [89]. This will affect agriculture, food security, livelihoods, and industry, because water consumption is high during the rabi season, when there is immense pressure to fulfil intensive agricultural needs in the absence of adequate rainfall.

With the contributions of glacier melt to the flow of the Brahmaputra diminishing, food security may be potentially affected in the upper Brahmaputra basin, but not in the lower Brahmaputra basin [3,4]. Sustained reduction in glacial contribution to the river flow in late winter or early spring may disturb the irrigation of rice in the pre-monsoon season [5]. Yang et al. (2016) foresee a problematic future for basin countries, as far as water supply for energy and food production is concerned. This projection is based on their study of the water-energy-food nexus considering fluctuations in temperature, rainfall, and upstream water diversion using a hydro-economic model. Rapid urbanization in the basin countries, especially in India and Bangladesh, could create more demand for water, energy, and other natural resources and lead to social destabilization and increased gender discrimination [5].

\section{Conclusions}

Communities in the South Asian region have a long history of successfully adapting to changes in the environment. However, in the face of the changing nature of water hazards, the traditional modes have proven to be less effective, making them more vulnerable. In addition, with climate change exacerbating the hazard events, understanding, and managing rivers requires sustainable and adaptive management options beyond the engineering measures that are conventionally used in such scenarios. The Brahmaputra river basin is key to the growth of the South Asian region because it is critical to meeting the demands for water and its uses for people and their livelihoods. In the changing context of the projected climate future, there is a need to balance the multiple demands for water between environmental management, social equity, and sustainable development of the basin communities and ecosystem. With increasing population and changing consumption patterns, it is likely that the demand for water from the Brahmaputra will rise, putting the basin's social, political, and economic stability at risk.

From a disaster risk resilience and basin management perspective, the integration between upstream and downstream communities is essential. Use of low-cost information and communication technology, such as early flood warnings using SMS and internetbased technology, could enhance upstream and downstream coordination and enable the real-time communication of upcoming disasters for preparedness. This can lead to social benefits through inter-state (province), cross-border, and transboundary collaboration on water resource management; it would help build trust, encourage the sharing of data and knowledge, and enhance disaster risk resilience. 
For the sustainable management and development of the basin, adopting a long-term perspective is necessary because it would increase the probability of implementing more immediate actions for adaptation, thereby enhancing both solutions and preparedness for future climate change. This emphasizes the need for a broader vision to become more inclusive and integrate various approaches that reflect critical interactions-both within and between different disciplines. The vision should also extend to all levels of management options, the governance mechanism, and the interface between local, national, and regional scales of intervention for the sustainable management of healthy rivers.

The planning process should incorporate local scenarios and voices that are cognizant of and factor in possible local climate and socioeconomic futures for better adaptation strategies. Riverine ecosystems, especially watersheds and wetlands, catchments, and the headwaters of river systems, should receive attention for the purpose of managing them and to use them wisely to enhance the lives and livelihoods of communities. This should be supported by scientific and evidence-based knowledge, including climate projections and scenario planning. For this to happen, the science-policy connection and conformity must be strengthened.

The absence of reliable and adequate hydrological, climatological, geomorphological, and socioeconomic data is a serious constraint for researchers and managers for developing models, scenarios, and knowledgebases. Therefore, it is important to share and exchange hydrological data and other relevant scientific information to build up a robust basin-scale knowledgebase which can be achieved through the promotion of scientific cooperation among the countries and relevant regional platforms.

Being a transboundary river, the Brahmaputra is managed differently in the different basin countries based on their respective national policies. Conflicts exist among the basin countries over management of the shared rivers that need to be addressed through adaptive hydro-diplomacy that exceed conventional diplomatic practices. A multilateral mechanism for regional cooperation needs to be established by the basin countries, based on their shared interest in reducing disaster and climate risk, equitable benefit-sharing from sustainable utilization of the water resources, and regional peace and prosperity of the basin region. Ensuring riverine connectivity and ecological health of the river by keeping the river free-flowing as far as possible should be one of the top priorities in a multilateral, collaborative, basin-wide co-management strategy.

Author Contributions: The conceptualization, methodology, analysis, and writing of the research article was collectively done by all the authors. All authors have read and agreed to the published version of the manuscript.

Funding: This study was supported by core funds of ICIMOD contributed by the Governments of Afghanistan, Australia, Austria, Bangladesh, Bhutan, China, India, Myanmar, Nepal, Norway, Pakistan, and Switzerland.

Acknowledgments: The views and interpretations in this publication are those of the authors. They are not necessarily attributable to ICIMOD and do not imply the expression of any opinion by ICIMOD concerning the legal status of any country, territory, city, or area of its authorities, or concerning the delimitation of its frontiers or boundaries, or the endorsement of any product. We are indebted to the reviewers for their constructive suggestions and inputs. We also thank ICIMOD's Knowledge Management and Communication unit, especially Rachana Chettri, and the external editor for language editing. We are grateful to PlusFish (supporting 'Research and engagement to protect aquatic biodiversity \& human food security') for covering the costs of publication, and Global Wildlife Conservation for assisting in logistics of the payment.

Conflicts of Interest: The authors declare no conflict of interest.

\section{References}

1. Bajracharya, S.R.; Shrestha, B. (Eds.) The Status of Glaciers in the Hindu Kush-Himalayan Region; ICIMOD: Kathmandu, Nepal, 2011.

2. Wester, P.; Mishra, A.; Mukherji, A.; Shrestha, A.B. (Eds.) The Hindu Kush Himalaya Assessment-Mountains, Climate Change, Sustainability and People; Springer Nature Switzerland AG: Cham, Switzerland, 2019. 
3. Immerzeel, W. Historical trends and future predictions of climate variability in the Brahmaputra basin. Int. J. Climatol. 2008, 28, 243-254. [CrossRef]

4. Immerzeel, W.; Beek, L.V.; Bierkens, M. Climate change will affect the Asian water towers. Science 2010, 328, 1382-1385. [CrossRef] [PubMed]

5. Ray, P.A.; Yang, Y.C.E.; Wi, S.; Khalil, A.F.; Chatikavanij, V.; Brown, C.M. Room for improvement: Hydroclimatic challenges to poverty-reducing development of the Brahmaputra River basin. Environ. Sci. Policy 2015, 54, 64-80. [CrossRef]

6. Yang, Y.C.E.; Wi, S.; Ray, P.A.; Brown, C.M.; Khalil, A.F. The future nexus of the Brahmaputra river basin: Climate, water, energy, and food trajectories. Glob. Environ. Chang. 2016, 37, 16-30. [CrossRef]

7. Rasul, G. Water for growth and development in the Ganges, Brahmaputra, and Meghna basins: An economic perspective. Int. J. River Basin Manag. 2015, 13, 387-400. [CrossRef]

8. Goswami, D.C.; Das, P.J. The Brahmaputra River, India: The eco-hydrological context of water use in one of world's most unique river systems. Ecol. Asia Rivers For. People Power 2003, 11, 9-14.

9. Gupta, N.; Mishra, A.; Agrawal, N.K.; Shrestha, A.B. Potential Impacts of Climate Change on Water Resources and Adaptation Policies in the Brahmaputra River Basin; Working Paper 2019/8; ICIMOD: Kathmandu, Nepal, 2019.

10. World Bank. Development and Growth in Northeast India: The Natural Resources, Water, and Environment Nexus; World Bank Report No. 36397-IN; The International Bank for Reconstruction and Development: Washington, DC, USA, 2007.

11. Goswami, D.C. Brahmaputra river, Assam, India: Physiography, basin denudation and channel aggradation. Water Resour. Res. 1985, 21, 959-978. [CrossRef]

12. Gupta, A. (Ed.) Large Rivers: Geomorphology and Management; John Wiley \& Sons Ltd.: Chichester, UK, 2007; 689p. [CrossRef]

13. Goswami, D.C. Fluvial regime and flood hydrology of the Brahmaputra river, Assam. Mem. Geol. Soc. India 1998, 41, 53-75.

14. Das, P.J. Rainfall regime of northeast India: A hydrometeorological study with special emphasis on the Brahmaputra basin. Ph.D. Thesis, Gauhati University, Guwahati, Assam, India, 2004. Available online: http:/ hdl.handle.net/10603/68298 (accessed on 1 October 2020).

15. Goswami, D.C.; Das, P.J. The Brahmaputra River, Assam: A Hydrogeomorphological Appraisal in Landforms Processes and Environment Management: Professor, M.K. Bandyopadhyay Felicitation Volume; Bandyopadhyay, S., Bhattacharji, M., Chaudhuri, S., Goswami, D.C., Jog, S.R., Kar, A., Eds.; ACB Publications: Kolkata, India, 2011; pp. 121-144.

16. Rahaman, M.M.; Varis, O. Integrated management of the Brahmaputra Basin: Constraints and hope for regional development. In XIII IWRA World Water Congress, Montpellier, France, 1-4 September 2008; International Water Resources Association/VERSEau Development: Montpellier, France, 2008.

17. Shrestha, A.B.; Agrawal, N.K.; Alfthan, B.; Bajracharya, S.R.; Maréchal, J.; van Oort, B. (Eds.) The Himalayan Climate and Water Atlas: Impact of Climate Change on Water Resources in Five of Asia's Major River Basins; ICIMOD: Kathmandu, Nepal, 2015.

18. Flügel, W.-A.; Pechstedt, J.; Bongartz, K.; Bartosch, A.; Eriksson, M.; Clark, M. Analysis of climate change trend and possible impacts in the Upper Brahmaputra River Basin-The Brahmatwinn Project. In Proceedings of the 13th IWRA World Water Congress 2008, Montpelier, France, 1-4 September 2008.

19. Apurv, T.; Mehrotra, R.; Sharma, A.; Goyal, M.K.; Dutta, S. Impact of climate change on floods in the Brahmaputra basin using CMIP5 decadal predictions. J. Hydrol. 2015, 527, 281-291. [CrossRef]

20. Van Vuuren, D.P.; Edmonds, J.; Kainuma, M.; Riahi, K.; Thomson, A.; Hibbard, K.; Masui, T. The representative concentration pathways: An overview. Clim. Chang. 2011, 109, 5. [CrossRef]

21. Lutz, A.F.; Maat, H.W.; Wijngaard, R.R.; Biemans, H.; Syed, A.; Shrestha, A.B.; Wester, P.; Immerzeel, W. South Asian river basins in a 1.50C warmer world. Reg. Environ. Chang. 2019, 19, 833-847. [CrossRef]

22. Pervez, M.S.; Henebry, G.M. Projections of the Ganges-Brahmaputra precipitation-Downscaled from GCM predictors. J. Hydrol. 2014, 517, 120-134. [CrossRef]

23. Wijngaard, R.R.; Lutz, A.F.; Nepal, S.; Khanal, S.; Pradhananga, S.; Shrestha, A.B.; Immerzeel, W.W. Future changes in hydroclimatic extremes in the Upper Indus, Ganges, and Brahmaputra River basins. PLoS ONE 2017, 12, e0190224. [CrossRef] [PubMed]

24. Mittermeier, R.A.; Robles, G.P.; Hoffmann, M.; Pilgrim, J.; Brooks, T.; Mittermeier, C.G.; Lamoreux, J.; da Fonseca, G.A.B. Hotspots Revisited: Earth's Biologically Richest and Most Endangered Ecoregions; CEMEX: Mexico City, Mexico, 2004; 391p.

25. Kottelat, M.; Whitten, T. Freshwater biodiversity in Asia with special reference to fish. World Bank Tech. Pap. 1996, $343,59$.

26. Vishwanath, W. Freshwater fish diversity of the Ganges-Brahmaputra-Meghna River Basin. In Rives for Life: Proceedings of the International Symposium on River Biodiversity: Ganges-Brahmaputra-Meghna River System, Ecosystems of Life, A Bangladesh-India Initiative; Sinha, R.K., Ahmed, B., Eds.; IUCN, International Union for Conservation of Nature: Dhaka, Bangladesh, 2014; 340p.

27. Dutta, R.; Bhagabati, S.K.; Baishya, S. Ichthyo-faunistic diversity of Northeast India—Status and future fishing, Chimes. April May 2018, 38, 54-60.

28. Sen, N. Occurrence, distribution, and status of diversified fish fauna of North East India. In Fish Biodiversity of North East India; Ponniah, A.G., Sarkar, U.K., Eds.; NBFGR, NATP Pub.: Lucknow, India, 2000; pp. 31-48.

29. Goswami, U.C.; Basistha, S.K.; Bora, D.; Shyamkumar, K.; Saikia, B.; Changsan, K. Fish diversity of North East India, inclusive of the Himalayan and Indo Burma biodiversity hotspots zones: A checklist on their taxonomic status, economic importance, geographical distribution, present status and prevailing threats. Int. J. Biodivers. Conserv. 2012, 4, 592-613. 
30. Biswas, S.P. An Overview on the threats of aquatic ecosystem in Upper Brahmaputra Basin. In Rivers for Life-Proceedings of the International Symposium on River Biodiversity: Ganges-Brahmaputra-Meghna River System; IUCN: Patna, India, $2014 ;$;p. 45-53.

31. Bhattacharjya, B.K.; Bhaumik, U.; Sharma, A.P. Fish habitat and fisheries of Brahmaputra River in Assam, India. Aquat. Ecosyst. Health Manag. 2017, 20, 102-115. [CrossRef]

32. Zhang, G.; Liu, D.; Li, F.; Qian, F.; Ma, T.; Dan, D.; Lu, J. Species and populations of waterbirds wintering in the Yarlung Zangbo and its tributaries in Tibet, China. Zool. Res. 2014, 35, 92-100.

33. SaciWATERs. Water Management Practices and Policies Along the Brahmaputra River Basin: India and Bangladesh-Status Report; South Asia Consortium for Interdisciplinary Water Resources Studies (SaciWATERs): Telangana, India, 2014; 59p.

34. Singh, B.; Goswami, R.K. Anthropogenic Influence on flow and sediment regime of a river basin. Int. J. Eng. Sci. Technol. 2012, 4, 30-37.

35. Chettri, N.; Sharma, E.; Shakya, B.; Thapa, R.; Bajracharya, B.; Uddin, K.; Oli, K.P.; Choudhury, D. Biodiversity in the Eastern Himalayas: Status, Trends and Vulnerability to Climate Change; Climate change Impact and Vulnerability in the Eastern Himalayas; Technical Report 2; ICIMOD: Kathmandu, Nepal, 2010.

36. Yasuda, Y.; Aich, D.; Hill, D.; Huntjens, P.; Swain, A. Transboundary Water Cooperation over the Brahmaputra River: Legal Political Economy Analysis of Current and Future Potential Cooperation; The Hague Institute for Global Justice: The Hague, The Netherlands, 2017.

37. Deka, B.C.; Thirugnanavel, A.; Patel, R.K.; Nath, A.; Deshmukh, N. Horticultural diversity in North-East India and its improvement for value addition. Indian J. Genet. 2010, 72, 157-167.

38. Chutia, S.J.; Yashwanth, B.S.; Baruah, A.K.; Kashyap, A.; Chetia, B.R.; Nath, B.B.; Choudhury, A.; Rathlavath, S.; Borah, S.; Chrispin, L.C. Trends in fish production of Assam: An analysis. Int. J. Curr. Microbiol. App. Sci. 2018, 7, 3417-3422. [CrossRef]

39. Grill, G.; Lehner, B.; Thieme, M.; Geenen, B.; Tickner, D.; Antonelli, F.; Babu, S.; Borrelli, P.; Cheng, L.; Crochetiere, H.; et al. Mapping the world's free-flowing rivers. Nature 2019, 569, 215-221. [CrossRef] [PubMed]

40. China to Build a Major Dam on Brahmaputra River. Available online: https://economictimes.indiatimes.com/news/ international/world-news/china-to-build-a-major-dam-on-brahmaputra-river-official/articleshow /79479127.cms?utm_ source $=$ contentofinterest\&utm_medium=text\&utm_campaign=cppst (accessed on 30 November 2020).

41. Buckley, M. Meltdown in Tibet: China's Reckless Destruction of Ecosystems from the Highlands of Tibet to the Deltas of Asia; Palgrave Macmillan: New York, NY, USA, 2014; 248p.

42. Bhattacharya, S. China's Hydro Ambitions, and the Brahmaputra, IDSA Backgrounder. 2018. Available online: https://idsa.in/ backgrounder/china-hydro-ambitions-and-the-brahmaputra-sbhattacharya-23 (accessed on 13 September 2020).

43. Bhalla, A. China's Dams in Tibet May Pose Threat to India's Water Supply I Satellite Images Explain. 2020. Available online: https:/ / www.indiatoday.in/india / story / china-s-dams-in-tibet-may-pose-threat-to-india-s-water-supply-satellite-imagesexplain-1709475-2020-08-09 (accessed on 15 August 2020).

44. Run-of-River Hydropower. Available online: https://www.ctc-n.org/technologies/run-river-hydropower (accessed on 12 October 2020).

45. Vagholikar, N.; Das, P.J. Damming Northeast India; Kalpavriksh, Aaranyak and Action Aid India: Pune, India; Guwahati, India; New Delhi, India, 2010; 20p.

46. Hijioka, Y.; Lasco, R.; Surjan, A.; Pereira, J. Climate Change Impacts, Adaptation, and Vulnerability. Part B: Regional Aspects. Available online: https://www.ipcc.ch/report/ar5/wg2/ (accessed on 10 September 2020).

47. Alfthan, B.; Gupta, N.; Gjerdi, H.L.; Schoolmeester, T.; Andresen, M.; Jurek, M.; Agrawal, N.K. Outlook on Climate Change Adaptation in the Hindu Kush Himalaya. Mountain Adaptation Outlook Series, 2018, United Nations Environment Programme, GRID-Arendal and the International Centre for Integrated Mountain Development, Vienna, Arendal and Kathmandu. Available online: www.unep.org (accessed on 10 September 2020).

48. Syed, A.; Haq, A.; Uzzaman, A.; Goodrich, C.G.; Mallick, D.; Mini, G.; Sharma, G.; Nyima, K.; Mamnun, N.; Varma, N.; et al. The Teesta Basin: Enough Water for Power and Agriculture for All; HI-AWARE Working Paper 12; HI-AWARE: Kathmandu, Nepal, 2017.

49. Dhar, O.N.; Nandargi, S. A study of floods in the Brahmaputra basin in India. Int. J. Climatol. J. Royal Meteorol. Soc. 2000, 20, 771-781. [CrossRef]

50. Mirza, M.M.Q.; Warrick, R.A.; Ericksen, N.J. The implications of climate change on floods of the Ganges, Brahmaputra and Meghna rivers in Bangladesh. Clim. Chang. 2003, 57, 287-318. [CrossRef]

51. Mirza, M.M.Q.; Warrick, R.A.; Wricksen, N.J.; Kenny, G.J. Are floods getting worse in the Ganges, Brahmaputra and Meghna basins? Environ. Hazards 2001, 3, 37-48. [CrossRef]

52. Gain, A.K.; Immerzeel, W.W.; Sperna Weiland, F.C.; Bierkens, M.F.P. Impact of climate change on the stream flow of lower Brahmaputra: Trends in high and low flows based on discharge-weighted ensemble modeling. Hydrol. Earth Syst. Sci. 2011, 15, 1537-1545. [CrossRef]

53. Ngana, J.; Notter, B.; Messerli, P.; Mbeyale, G.; Msuya, T.; Chitiki, A. Managing water resources in dynamic settings: A multi-level, multi-stakeholder perspective. Glob. Chang. Sustain. Dev. 2019, 5, 91-106.

54. Das, P.J.; Bhuyan, H.K. Policy and Institutions in Adaptation to Climate Change: Case Study on Flood Mitigation Infrastructure in India and Nepal, 2013. ICIMOD Work. Pap. 2013, 4, 38.

55. ADB, Assam Integrated Flood and Riverbank Erosion Risk Management Investment Program (RRP IND 38412): Subsector Assessment (Summary): Flood Protection, Asian Development bank-India. 2010. Available online: https://www.adb.org/sites/ default/files/linked-documents/38412-01-ind-ssa.pdf (accessed on 15 September 2020). 
56. Tschakert, P.; Das, P.J.; Pradhan, N.S.; Machado, M.; Lamadrid, A.; Buragohain, M.; Hazarika, M.A. Micropolitics in collective learning spaces for adaptive decision-making. Glob. Environ. Chang. 2016, 40, 182-194. [CrossRef]

57. Varma, N.; Kelkar, U.; Bhardwaj, S.; Singh, P.; Mishra, A. Climate change, disasters, and development: Testing the waters for adaptive governance in India, Vision. J. Bus. Perspect. 2014, 18, 327-338. [CrossRef]

58. Samaranayake, N.; Limaye, S.; Wuthnow, J. Water Resource Competition in the Brahmaputra River Basin: China, India, and Bangladesh; Centre for Naval Analyses: Alexandria, VA, USA, 2016; 100p.

59. Siddiqui, S.; Chohan, S.; Das, P.J. Reimagining Brahmaputra: Policy and Regulatory Aspects of Transboundary Water Governance; Oxfam: New Delhi, India, 2018.

60. Das, A.; Das, P.J. Local solutions to local disasters: Governance in flood management in Assam, pp. 152-170. In 'Bottomup' Approaches in Governance and Adaptation for Sustainable Development: Case Studies from India and Bangladesh; Swarnakar, P., Zavestoski, S., Pattnaik, B., Eds.; SAGE Publications: New Delhi, India, 2017; p. 368.

61. Seliger, C.; Zeiringer, B. River Connectivity, Habitat Fragmentation and Related Restoration Measures. In Riverine Ecosystem Management Science for Governing Towards a Sustainable Future; Schmutz, S., Sendzimir, J., Eds.; Springer Open: New York, NY, USA, 2015; pp. 171-186.

62. Climate Technology Centre \& Network, 2020. CWC, Guidelines for Maintaining Longitudinal Connectivity through Dams, 2017. Central Water Commission, Government of India, New Delhi. Available online: https:/ / www.ctc-n.org/technologies/run-riverhydropower (accessed on 23 November 2020).

63. Modal, C.; Solomon, M.; Tew, B.; Gerhman, B.; Lehner, C. Analysis of Reservoir-Based Hydroelectric versus Run-of-River Hydroelectric Energy Production; Land Resources and Environmental Sciences Montana State University: Bozeman, MT, USA, 2014.

64. Olden, J.D.; Naiman, R.J. Incorporating thermal regimes into environmental flows assessments: Modifying dam operations to restore freshwater ecosystems integrity. Freshw. Biol. 2010, 55, 86-107. [CrossRef]

65. Nandy, D.R. Geodynamics of North Eastern India and the Adjoining Region; ACB Publications: Kolkata, India, 2001; 209p.

66. Goswami, D.C.; Das, P.J. Hydrological impact of earthquakes on the Brahmaputra river regime, Assam: A study in exploring some evidence. In Proceedings of the 18th National Convention of Civil Engineers, November 9-10, 2002. Institution of Engineers (India); Assam State Center: Guwahati, India, 2002; pp. 40-48.

67. Anukularmphai, A. Implementing integrated water resources management (IWRM): Based on Thailand's Experience, Report; IUCN Asia Regional Office: Bangkok, Thailand, 2010.

68. Nepal, S.; Shrestha, A.B.; Goodrich, C.G.; Mishra, A.; Prakash, A.; Bhuchar, S.; Vasily, L.A.; Khadgi, V.; Pradhan, N.S. (Eds.) Multi-scale Integrated River Basin Management (IRBM) from a Hindu Kush Himalayan Perspective, Resource Book; ICIMOD: Kathmandu, Nepal, 2019.

69. Fanaian, S.; Deka, A.; Gulati, V. Towards collaborative transboundary river governance. ENVIS Newsl. Himal. Ecol. 2016, 13, 6.

70. Gupta, N.; Mishra, A.; Agrawal, N.K.; Satapathy, S. Interstate cooperation for climate change adaptation in Indian Himalayan region. Econ. Political Wkly. 2018, 53, 35-40.

71. Framework Agreement on Cooperation for Development between Government of the Republic of India and Government of the People's Republic of Bangladesh. Available online: https://www.mea.gov.in/Portal/LegalTreatiesDoc/BG11B0571.pdf (accessed on 23 September 2020).

72. Pangare, G. (Ed.) Hydro-diplomacy: Sharing Water Across Borders; Academic Foundation: New Delhi, India, 2014; 154p.

73. Indo-Bangladesh Cooperation. Available online: http://mowr.gov.in/international-cooperation/bilateral-cooperation-withneighbouring-countries/indo-bangladesh-cooperation (accessed on 24 September 2020).

74. Statute of the Indo-Bangladesh Joint Rivers Commission. Available online: https:/ /www.internationalwaterlaw.org/documents / regionaldocs/indo-bangladesh.html (accessed on 28 September 2020).

75. Trade between India and Bangladesh. Available online: https://www.mea.gov.in/Portal/LegalTreatiesDoc/BG15B2412.pdf (accessed on 25 August 2020).

76. Protocol on Inland Water Transit and Trade. Available online: https:/ / economictimes.indiatimes.com/topic/Protocol-on-InlandWater-Transit-and-Trade/news? from $=m d r$ (accessed on 5 October 2020).

77. Field, C.B.; Barros, V.; Stocker, T.F.; Qin, D.; Dokken, D.J.; Ebi, K.L.; Mastrandrea, M.D.; Mach, K.J.; Plattner, G.K.; Allen, S.K.; et al. (Eds.) Managing the Risks of Extreme Events and Disasters to Advance Climate Change Adaptation; Cambridge University Press: Cambridge, UK, 2012; 582p.

78. Vaidya, R.A.; Shrestha, M.S.; Nasab, N.; Gurung, D.R.; Kozo, N.; Pradhan, N.S.; Wasson, R.J. Disaster Risk Reduction and Building Resilience in the Hindu Kush Himalaya. In The Hindu Kush Himalaya Assessment; Wester, P., Mishra, A., Mukherji, A., Shrestha, A., Eds.; Springer Nature Switzerland AG: Cham, Switzerland, 2019; pp. 389-419.

79. Mishra, A.; Agrawal, N.K.; and Gupta, N. Building Mountain Resilience: Solutions from the Hindu Kush Himalaya; ICIMOD: Kathmandu, Nepal, 2017.

80. Gupta, N.; Raghavan, R.; Sivakumar, K.; Mathur, V.B. Freshwater Fish Safe Zones (FFSZs): A prospective conservation strategy for river ecosystems in India. Curr. Sci. 2014, 107, 949-950.

81. ADB's Work in Bangladesh. Available online: https://www.adb.org/countries/bangladesh/overview (accessed on 8 October 2020). 
82. World Bank Helps Bangladesh Ensure Safe Water and Sanitation in Rural Areas. Available online: https://www.worldbank. org/en/news/press-release/2020/09/25/world-bank-helps-bangladesh-ensure-safe-water-and-sanitation-in-rural-areas (accessed on 29 September 2020).

83. ADB, India Sign $\$ 60$ Million Loan to Reduce Floods and Riverbank Erosion in Assam. Available online: https://www.adb.org/ news/adb-india-sign-60-million-loan-reduce-floods-and-riverbank-erosion-assam (accessed on 27 November 2019).

84. Flood and River Erosion Management Agency of Assam. Available online: http://sdmassam.nic.in/download/workshop_ riverbank_erosion/Ppt_by_FREMAA.pdf (accessed on 27 December 2019).

85. Project Signing: World Bank Approves $\$ 88$ Million Project to Help Modernize Waterways in Assam. Available online: https:/ / www.worldbank.org/en/news / press-release/2020/01/16/world-bank-help-modernize-waterways-assam (accessed on 27 November 2020).

86. Haque, S.; Ali, M.M.; Saiful Islam, A.K.M.; Khan, J.U. Changes in flow and sediment load of poorly gauged Brahmaputra river basin under an extreme climate scenario. J. Water Clim. Chang. 2022, jwc2020219. [CrossRef]

87. Mohammed, K.; Islam, A.S.; Islam, G.M.T.; Alferi, L.; Bala, S.K.; Khan, M.J.U. Impact of high-end climate change on floods and low flows of the Brahmaputra river. J. Hydrol. Eng. 2017, 22, 10. [CrossRef]

88. Fischer, S.; Pietron, J.; Bring, A.; Thorslund, J.; Jarsj, J. Present to future sediment transport of the Brahmaputra River: Reducing uncertainty in predictions and management. Reg. Environ. Chang. 2017, 17, 515-526. [CrossRef]

89. Gain, A.; Wada, Y. Assessment of Future Water Scarcity at Different Spatial and Temporal Scales of the Brahmaputra River Basin. Water Resour. Manag. 2014, 28, 999-1012. [CrossRef] 